\title{
EFFECT OF GENETICALLY MODIFIED FEEDS ON PHYSICO-CHEMICAL PROPERTIES OF PORK
}

\author{
Joanna Stadnik ${ }^{1}$, Małgorzata Karwowska ${ }^{1}$, \\ Zbigniew Józef Dolatowski ${ }^{1}$, Małgorzata Świątkiewicz ${ }^{2}$, \\ Krzysztof Kwiatek ${ }^{3}$
}

\author{
'Department of Meat Technology and Food Quality, University of Life Sciences in Lublin, \\ 20-704 Lublin, Poland \\ ${ }^{2}$ Department of Animal Nutrition and Feed Science, National Research Institute of Animal Production, \\ 32-083 Balice n. Kraków, Poland \\ ${ }^{3}$ Department of Hygiene of Animal Feedingstuffs, National Veterinary Research Institute, \\ 24-100 Puławy, Poland \\ Corresponding author: joanna.stadnik@up.lublin.pl
}

\begin{abstract}
The objective of this study was to evaluate the effects of genetically modified (GM), insect-resistant $B t$ maize (MON810) and the meal made of glyphosate-tolerant soybean (Roundup Ready MON40-3-2) used as the dietary components for pigs on the physico-chemical properties of meat. Forty-eight fatteners derived from Polish Landrace $\times$ Polish Large White sows mated to a Duroc $\times$ Pietrain boar were used. All animals received isonitrogenous and isoenergetic diets containing or not containing the genetically modified components. The design of the experiment was as follows: group I (control) - non-modified soybean meal and maize; group II - GM soybean meal and nonmodified maize; group III - non-modified soybean meal and GM maize; group IV - GM soybean meal and GM maize. The examination of the $\mathrm{pH}$ values of loin and neck muscles indicated no statistically significant differences between pigs fed diets containing non-transgenic or transgenic feeds. No statistical differences were observed for water holding capacity (WHC) within dietary treatments. The introduction of transgenic maize and soybean meal into pig diets did not significantly affect the a* colour parameter of loin as well as neck muscles. The use of transgenic maize or soybean meal did not cause significant changes in the $\mathbf{L}^{*}$ colour value of loin. Results obtained for neck muscles were more differentiated, possibly due to the natural heterogeneity of this primal cut. Pigs which had consumed the transgenic diet exhibited slightly decreased lipid stability of loin, as indicated by thiobarbituric acid reactive substances (TBARS). The decrease was statistically significant only in the case of muscles from group II. The addition of feeds derived from genetically modified crops into pig diets did not significantly affect the stability of neck muscle lipids; however, TBARS values of these muscles were twice those of loin muscles.
\end{abstract}

Key words: pigs, genetically modified feeds, physico-chemical properties, muscles 
Meat safety concerns, challenges and related issues that will be still relevant in the 21 st century are divided into those associated with microbial pathogens and into other meat safety issues. The category of other meat safety concerns includes food additives, chemical residues, products of food biotechnology or genetically modified organisms (GMO), and intentional bioterrorism concerns (Sofos, 2008). A major priority for recent research has been treatments that have potential to ensure safe, consistent, high-quality products. In this respect modern biotechnology would allow huge advances to be made. However, we must ensure that ethical, legal, and consumer concerns are met (Garnier et al., 2003).

Genetically modified (GM) plants are those in which one or more new DNA constructs originating from foreign organisms have been integrated. The genetic modifications mainly aimed at protection against insects, tolerance to herbicides and pesticides or improved quality traits offer a variety of benefits to growers (Aeschbacher et al., 2005). The worldwide cultivation of GM crops in 25 countries in 2009 was 134 million hectares. In comparison with 1.7 million hectares in six countries in 1996, it has been a 79-fold increase, which made GM crops the fastest adopted crop technology in recent history (Aeschbacher et al., 2005; Flachowsky et al., 2007; James, 2009). The principal biotech crop is GM soybean which occupied $52 \%$ of the global biotech area in 2009 , followed by maize $(31 \%)$, cotton $(12 \%)$, and canola (5\%) (James, 2009). GM plants are becoming an increasing part of animal feed ingredients. The constant increase of GM crops production will be followed by their growing consumption by animals reared for food.

Soybeans are a major source of protein in the diets of most farm animals. GM soybeans are produced by the introduction of a gene coding for 5-enolpyruvylshikimate-3-phosphate synthase from Agrobacterium sp. strain CP4 (CP4 EPSPS) that confers tolerance to glyphosate. Glyphosate-tolerant soybeans (GTS), marketed under the trade name Roundup Ready (a registered trademark of Monsanto Technology LLC), are able to grow and develop normally after foliar application of the glyphosate, the active ingredient of a commonly used herbicide Roundup (Chainark et al., 2006; Cromwell et al., 2002; Hammond et al., 1996; McCann et al., 2005; Padgette et al., 1996).

GM maize became the second most significant biotech crop after GM soybeans in 2007, and the first one to have a wider variety of genetic modifications than GTS (Magaña-Gómez and Calderón de la Barca, 2009). GM maize, introduced to the market in 1996, contains the gene originating from common soil bacterium Bacillus thuringiensis $(B t)$ coding for a crystalline protein Cry1A(b). This protein is an endotoxin with specific activity against certain Lepidopterans maize pests such as the European corn borer (Ostrinia nubilalis) and thus potentially minimizes the use of insecticides (Aeschbacher et al., 2005; Flachowsky et al., 2007; Rossi et al., 2005).

The safety of foods and feeds derived from genetically modified crops has been the subject of many emotional discussions, studies, and publications. The most frequent topics in the current debate over GM crops are the advantages to developing countries, economic issues, environmental impact, ethical and social considerations, and public confidence in regulatory procedures for GM crops. However, the main question is whether or not they are safe for the environment or for human health. 
From the beginning, there were concerns not about the technology but about its possible consequences like the possibility of unintentional creation of plant species that are super-resistant to herbicides or antibiotics or unintended effects for human health. Among the potential threats to human health that have been listed are toxicity and allergenicity of the newly produced proteins. Other questions address the instability of the inserted gene and negative effects on nutrition. The controversy about the environmental and health safety of GMO is complex and more scientific efforts and investigations are needed to ensure that consumption of GM foods is not likely to provoke any form of health problem (Aeschbacher et al., 2005; Magaña-Gómez and Calderón de la Barca, 2009; Rossi et al., 2005).

As pork is the most commonly consumed meat worldwide, it is necessary to pay more attention to the issue of physico-chemical properties as well as to the conditions of its production. The manipulation of the sensorial and nutritional quality of meat through animal nutrition strategies is gaining growing importance. Modern biotechnology would allow huge advances to be made in this respect. However, to our knowledge, the scientific literature contains limited information regarding the physico-chemical properties of meat from pigs fed GM feed. Pork assessment is usually limited to chemical meat composition, accompanied by characteristics of carcass quality directly after slaughter or $24 \mathrm{~h}$ postmortem (Cromwell et al., 2002; Hyun et al., 2004, 2005; Mlynek et al., 2009). As far as technological suitability is concerned, meat characteristics after ageing is indispensable as quality of pork is formed at all stages of production, starting with animal breeding and nutrition (Florowski et al., 2006). Therefore, the aim of this study was to evaluate the effects of genetically modified, insect-resistant Bt maize (MON810) and glyphosate-tolerant soybean meal (Roundup Ready MON40-3-2) used as the main dietary components for pigs on the physico-chemical properties of meat after seven days of ageing.

\section{Material and methods}

The animals were raised as part of a feeding experiment aimed at evaluating fattening results and transfer of transgenic DNA to swine tissues fed conventional or transgenic soybean meal and maize (Świątkiewicz et al., 2011).

The experiment was carried out on 48 fatteners derived from Polish Landrace $x$ Polish Large White sows mated to a Duroc $\times$ Pietrain boar. Fatteners were kept in individual straw bedded pens and were twice daily fed individually with restricted amounts of feed according to body weight, which was controlled every two weeks. During the trial animals had free access to water. In all mixtures the barley, wheat and maize grain, soybean meal, wheat bran, vitamin-mineral additives and crystalline amino acids were used and the diets were isonitrogenous and isoenergetic. Grower diets (first fattening period, 30-60 kg BW) contained 12.6 MJ ME, $175 \mathrm{~g}$ crude protein, $9.7 \mathrm{~g}$ Lys and $6.1 \mathrm{~g} \mathrm{Met}+\mathrm{Cys}$ while the finisher diet (second fattening period, 60-110 kg BW) contained 12.6 MJ ME, $160 \mathrm{~g}$ crude protein, $8.1 \mathrm{~g}$ Lys and $5.3 \mathrm{~g} \mathrm{Met}+$ Cys. The diets used in the experiment differed in presence of the geneti- 
cally modified or non-modified soybean meal (18\% in grower and $14 \%$ in finisher diet) and maize grain (13\% in grower and 10\% in finisher diet). This experiment concerned the grain of maize (MON810) modified with $B t$ gene for protection against the corn borer and soybean meal produced from glyphosate-tolerant Roundup Ready soybean (MON40-3-2). The design of the experiment was as follows: group I (control) - non-modified soybean meal and non-modified maize; group II - GM soybean meal and non-modified maize; group III - non-modified soybean meal and GM maize; group IV - GM soybean meal and GM maize. The Local Ethic Committee for Experiments with Animals approved all of the experimental procedures relating to the use of live animals. At the end of the fattening period which lasted from about 30 to $110 \mathrm{~kg} \mathrm{BW}$, all pigs were slaughtered.

Directly after slaughter two primal cuts: loin ( $m$. longissimus dorsi from the area of the last thoracic and first lumbar vertebrae - sample L) and the top of the neck ( $m$. biventer cervicis and m. splenius - sample N) were excised from six carcasses of each experimental group.

The primal cuts were packed individually into HDPE bags and subjected to evaluation after 7 days of postmortem ageing at $+4^{\circ} \mathrm{C}$. $\mathrm{pH}$ measurement was conducted according to the Polish Standard PN-ISO 2917 (2001). Water holding capacity (WHC) was determined using the centrifugation method (Wierbicki et al., 1962). In order to assess the total oxidative or reducing capacity of the meat system, oxidation-reduction potential (ORP) was determined according to the method of Nam and Ahn (2003). ORP is one of environmental factors affecting the growth of bacteria and subsequent storage stability of meat. Colour parameters (CIE L*a*b*) were measured on freshly cut muscle surface using an X-Rite Color ${ }^{\circledR}$ Premiere 8200 spectrophotometer (X-Rite Incorporated, USA) following the recommendations of the American Meat Science Association (1991). The instrumental conditions were a 3.32 inch diameter area aperture, illuminant D65, and a $10^{\circ}$ standard observer. Lipid oxidation was determined by analysing the values of thiobarbituric acid reactive substances - TBARS (malondialdehyde/kg meat) following the procedure of Pikul et al. (1989).

Measurements were carried out in three replications for each sample. The data obtained were statistically analysed using the Statgraphics v. 5. One-way analysis of variance was performed. Significance of differences between the feeding groups was tested (at the significance level $\mathrm{P} \leq 0.05$ ) using Tukey's test.

\section{Results}

Results of $\mathrm{pH}$ measurements obtained for neck muscles were higher than those of loin. The examination of the $\mathrm{pH}$ values indicated no statistically significant differences between pigs fed diets containing non-transgenic or transgenic feeds (Table 1).

Table 1 shows the results of the water holding capacity measurements carried out for primal cuts. No statistical differences were observed in WHC within dietary treatments. The WHC values of loin were higher than those of neck muscles. 
Table 1. Physico-chemical properties of meat from pigs fed conventional or GM maize and soybean meal

\begin{tabular}{l|c|c|c|c|c|c}
\hline \multirow{2}{*}{$\begin{array}{c}\text { Treatment } \\
\text { group }\end{array}$} & \multicolumn{2}{|c|}{$\mathrm{pH}$} & \multicolumn{2}{c|}{ WHC (\%) } & \multicolumn{2}{c}{ ORP $(\mathrm{mV})$} \\
\cline { 2 - 7 } & $\mathrm{L}$ & $\mathrm{N}$ & $\mathrm{L}$ & $\mathrm{N}$ & $\mathrm{L}$ & $\mathrm{N}$ \\
\hline $\mathrm{I}$ & $5.58 \mathrm{a} \pm 0.5$ & $6.03 \mathrm{a} \pm 0.9$ & $53.83 \mathrm{a} \pm 3.7$ & $37.41 \mathrm{a} \pm 9.7$ & $342.6 \mathrm{a} \pm 5.8$ & $329.1 \mathrm{a} \pm 5.6$ \\
$\mathrm{II}$ & $5.55 \mathrm{a} \pm 0.3$ & $5.96 \mathrm{a} \pm 0.6$ & $50.03 \mathrm{a} \pm 3.6$ & $34.14 \mathrm{a} \pm 8.4$ & $391.1 \mathrm{~b} \pm 9.8$ & $350.9 \mathrm{~b} \pm 3.9$ \\
III & $5.48 \mathrm{a} \pm 0.7$ & $6.00 \mathrm{a} \pm 0.8$ & $50.93 \mathrm{a} \pm 4.7$ & $33.76 \mathrm{a} \pm 9.4$ & $326.7 \mathrm{c} \pm 8.0$ & $348.3 \mathrm{~b} \pm 9.4$ \\
$\mathrm{IV}$ & $5.57 \mathrm{a} \pm 0.4$ & $6.06 \mathrm{a} \pm 0.4$ & $55.08 \mathrm{a} \pm 3.8$ & $36.66 \mathrm{a} \pm 7.6$ & $351.7 \mathrm{a} \pm 5.9$ & $334.9 \mathrm{a} \pm 2.9$ \\
\hline
\end{tabular}

$\mathrm{a}, \mathrm{b}, \mathrm{c}-$ values in columns followed by different letters differ significantly $(\mathrm{P} \leq 0.05)$.

$\mathrm{L}-$ loin, $\mathrm{N}-$ neck muscles, $\pm \mathrm{SD}$.

The oxidation-reduction potential of loin (Table 1) varied from 326.7 to $391.1 \mathrm{mV}$ across dietary treatments. Results for redox measurements of the muscles from the group fed non-modified soybean meal and GM maize (group III) were lower than those obtained for muscles from other groups. This suggests that those samples had lower oxidizing potential. The highest results of ORP measurements were obtained for the muscles from the group fed GM soybean meal and non-modified maize (group II). As far as measurements of neck muscles are concerned, no statistically significant differences were noted between results obtained within groups I and IV as well as within groups II and III.

Table 2. Colour parameters of meat from pigs fed conventional or GM maize and soybean meal

\begin{tabular}{l|c|c|c|c|cc}
\hline \multirow{2}{*}{$\begin{array}{c}\text { Treatment } \\
\text { group }\end{array}$} & \multicolumn{2}{|c|}{$\mathrm{L}^{*}$} & \multicolumn{2}{c|}{$\mathrm{a}^{*}$} & \multicolumn{3}{c}{$\mathrm{b}^{*}$} \\
\cline { 2 - 7 } & $\mathrm{L}$ & $\mathrm{N}$ & $\mathrm{L}$ & $\mathrm{N}$ & $\mathrm{L}$ & $\mathrm{N}$ \\
\hline I & $60.50 \mathrm{a} \pm 2.9$ & $51.37 \mathrm{a} \pm 2.6$ & $1.20 \mathrm{a} \pm 0.3$ & $5.55 \mathrm{a} \pm 1.5$ & $9.38 \mathrm{bd} \pm 0.8$ & $10.12 \mathrm{a} \pm 1.4$ \\
II & $58.37 \mathrm{a} \pm 0.8$ & $55.58 \mathrm{c} \pm 5.6$ & $1.28 \mathrm{a} \pm 0.2$ & $5.38 \mathrm{a} \pm 1.6$ & $9.49 \mathrm{~cd} \pm 0.6$ & $10.43 \mathrm{a} \pm 2.2$ \\
III & $58.74 \mathrm{a} \pm 4.5$ & $48.05 \mathrm{ab} \pm 3.3$ & $1.59 \mathrm{a} \pm 0.5$ & $6.69 \mathrm{a} \pm 1.6$ & $9.94 \mathrm{abc} \pm 0.6$ & $10.28 \mathrm{a} \pm 1.6$ \\
IV & $59.19 \mathrm{a} \pm 0.6$ & $45.96 \mathrm{~b} \pm 0.4$ & $1.45 \mathrm{a} \pm 0.5$ & $6.49 \mathrm{a} \pm 1.5$ & $10.49 \mathrm{a} \pm 0.5$ & $9.77 \mathrm{a} \pm 1.4$ \\
\hline
\end{tabular}

$\mathrm{a}, \mathrm{b}, \mathrm{c}, \mathrm{d}-$ values in columns followed by different letters differ significantly $(\mathrm{P} \leq 0.05)$.

$\mathrm{L}-$ loin, $\mathrm{N}-$ neck muscles, $\pm \mathrm{SD}$.

Table 2 shows results of $\mathrm{L}^{*} \mathrm{a}^{*} \mathrm{~b}$ * colour coordinate measurements taken for the examined primal cuts. In the case of the loin, the use of transgenic maize or soybean meal did not cause significant changes in colour parameter $\mathrm{L}^{*}$. Results obtained for neck muscles were more differentiated. The differences may result from the natural heterogeneity of this primal cut. Incorporation of transgenic maize and soybean meal into pig diets did not significantly affect the $\mathrm{a}^{*}$ colour parameter of loin as well as neck muscles. No statistically significant effect of dietary treatment on the blue-yellow chromatic (b*) values of neck muscles was observed (Table 2). Loins of group IV (GM soybean meal and GM maize) had significantly higher values of coordinate $b^{*}$ than the samples of group I (control) and loins from pigs fed GM soybean meal and non-modified maize (group II). No significant differences were noted between 
loins from the group fed non-modified soybean meal and GM maize (group III) and loins of group IV.

Table 3. TBARS values of meat from pigs fed conventional or GM maize and soybean meal

\begin{tabular}{l|r|c}
\hline \multirow{2}{*}{ Treatment group } & \multicolumn{2}{|c}{ TBARS $(\mathrm{mg} / \mathrm{kg})$} \\
\cline { 2 - 3 } & $0.86 \mathrm{ac} \pm 0.05$ & $\mathrm{~N}$ \\
\hline I & $1.04 \mathrm{~d} \pm 0.14$ & $2.13 \mathrm{a} \pm 0.46$ \\
II & $0.92 \mathrm{ab} \pm 0.06$ & $2.32 \mathrm{a} \pm 0.44$ \\
III & $0.90 \mathrm{bc} \pm 0.05$ & $2.18 \mathrm{a} \pm 0.11$ \\
IV & & $2.47 \mathrm{a} \pm 0.36$ \\
\hline
\end{tabular}

$\mathrm{a}, \mathrm{b}, \mathrm{c}, \mathrm{d}$ - values in columns followed by different letters differ significantly $(\mathrm{P} \leq 0.05)$.

$\mathrm{L}-$ loin, $\mathrm{N}-$ neck muscles, $\pm \mathrm{SD}$.

The results (Table 3 ) showed that pigs which had consumed transgenic diet exhibited slightly decreased lipid stability of loin muscle, as indicated by TBARS values (malondialdehyde $\mathrm{mg} / \mathrm{kg}$ meat). The decrease was statistically significant only for muscles from pigs fed the diet composed of GM soybean meal and non-modified maize (group II). The addition of feeds derived from genetically modified crops into pig diets did not significantly affect the stability of neck lipids.

\section{Discussion}

The aim of the present study was to evaluate the effects of genetically modified, insect-resistant $B t$ maize (MON810) and glyphosate-tolerant soybean meal (Roundup Ready MON40-3-2) used as the dietary components for pigs on the physicochemical properties of meat after seven days of ageing.

This experiment constitutes part of a study described in a previous paper (Świątkiewicz et al., 2011), which addressed the effect of Roundup Ready soybean meal and Bt maize MON810 on fattening indices and meat quality in pigs, as well as the possibility of transfer of transgenic DNA to swine tissues. The results of this paper demonstrated that glyphosate-tolerant soybean meal and insect-resistant maize incorporated into pig diets did not affect the fattening results. No statistically significant differences were noticed in carcass measurements. There were also no statistically confirmed differences between the experimental groups in respect of quality indices and chemical composition of meat. No transgenic RR or $B t$ DNA was detected in any tissues and in the content of distal parts of the alimentary tract. The transgenes were present only in stomach and duodenum content, which confirms the efficiency of the digestion process in the gastrointestinal tract. Cromwell et al. (2002) demonstrated that Roundup Ready soybean meal is nutritionally equivalent to conventional soybean meal for growing-finishing swine and results in similar quality of pork, which was confirmed in the present study. Previous research has also demonstrated that insect-protected maize (MON810) was comparable to its near-isogenic, con- 
ventional counterparts in terms of nutrient composition (Gaines et al., 2001) and growth performance as well as carcass quality of growing-finishing pigs (Weber and Richert, 2001). Substantial equivalence is a part of nutritional assessment which is usually followed by the evaluation of fattening performance of animals and the fate of foreign DNA in their bodies. Apart from that, quality of raw material, which is important from the point of view of meat technologists and consumers should also be assessed.

The results obtained revealed that insect-resistant maize (MON810) and glyphosate-tolerant soybean meal (Roundup Ready) used as feed components in pig diets did not significantly affect the $\mathrm{pH}$ of the examined primal cuts (loin and neck muscles) for all experimental groups. Higher values obtained for neck muscles may result from the differences in glycolytic metabolism between red and white fibres (Bereta and Eckert, 2010).

The results confirmed no statistical differences in water holding capacity within dietary treatments. WHC (the ability to retain inherent and added water) is an important property of meat as it affects both the yield and the quality of the end product. Higher WHC values of loin suggest its greater ability to retain water during processing. Similar results were observed by Hyun et al. (2004), who showed no difference between the Roundup Ready hybrid tested relative to the conventional maize for longissimus muscle quality.

$\mathrm{L}^{*} \mathrm{a}{ }^{*} \mathrm{~b}$ colour parameters were generally similar across dietary treatments, with the exception of small differences between $L^{*}$ values for neck muscles and $b^{*}$ values for loin. Loin lightness values were slightly higher than those obtained for neck. These results are in agreement with Golding-Myers et al. (2010), who reported that the higher $\mathrm{L}^{*}$ value of loin compared to neck should be related to a higher proportion of white muscle fibres in loin muscle than in neck muscles. There were also no statistically confirmed differences between the experimental groups in respect of the $a^{*}$ colour parameter of loin as well as neck muscles. The higher a* value of neck muscles might be correlated with its higher myoglobin content and muscle fibre composition (Bereta and Eckert, 2010). Glyphosate-tolerant soybean meal and insect-resistant maize incorporated into pig diets did not affect the blue-yellow chromatic ( $\left.b^{*}\right)$ values of neck muscles. Hyun et al. (2005), in a study aimed at evaluating growth performance and carcass quality in growing-finishing pigs fed a diet containing YieldGard Rootworm maize (MON863), a genetically similar non-transgenic maize, or non-transgenic commercial maize hybrids revealed no differences in $\mathrm{L}^{*} \mathrm{a} \mathrm{b}^{*}$ colour parameters between samples.

Lipid oxidation is a major deteriorative process in meats during storage. It is responsible for a wide variety of undesirable reactions such as the loss of nutritional and sensory values as well as the formation of potentially toxic compounds that compromise meat quality and reduce its shelf life. One such product is malondialdehyde (MDA), which has long been considered as an index of oxidative rancidity. Among all the methods proposed for assessing MDA, the 2-thiobarbituric acid reactive substances (TBARS) value has been widely adopted as a sensitive assay method for the assessment of degree of lipid oxidation in meat during storage (Pikul et al., 1989). The major factors affecting the deterioration of meat quality through lipid oxidation, 
reflected by TBARS value, include the total lipid content, their fatty acid composition and endogenous prooxidative or antioxidative constituents which are dependent on animal species, muscle type, and anatomical location of muscle (Min and Ahn, 2005). Other factors that will affect the lipid oxidation of meat are the presence of free metal ions, heme pigments, oxygen availability, mechanical processes, cooking and the addition of salt during the processing procedures (Kanner et al., 1988). There were no statistically confirmed differences between the experimental groups in respect of TBARS values of neck muscles. The data obtained for loin did show some, but negligible, differences between treatments. Pigs which had consumed transgenic diet exhibited slightly decreased lipid stability but the decrease was statistically significant only in the case of muscles from pigs fed the diet composed of GM soybean meal and non-modified maize. Higher TBARS values obtained for neck may result from the differences in fat content between the examined primal cuts. The susceptibility of meat to lipid oxidation is also influenced by differences in heme pigment content and catalase activity. Meats with higher heme pigment content (neck) produce more hydrogen peroxide $\left(\mathrm{H}_{2} \mathrm{O}_{2}\right)$ during oxymyoglobin autooxidation than meats with less heme pigments (loin). Hydrogen peroxide can react with metmyoglobin to generate ferrylmyoglobin, which can initiate lipid oxidation (Min et al., 2008).

The oxidation-reduction potential of loin and neck muscles varied across dietary treatments. Loins from the group fed non-modified soybean meal and GM maize had less oxidizing potential than samples from other groups. As far as neck muscles are concerned, no statistically significant differences were noted between ORP values obtained within groups I and IV as well as within groups II and III. ORP of meat is highly variable depending on changes in the $\mathrm{pH}$, microbial growth, packaging, and the partial pressure of oxygen in the storage environment. Therefore, further investigations should be undertaken to explain the effects of diet on ORP observed in the present study, because to our knowledge, no data concerning the effects of GM feed on oxidation-reduction potential of pig meat are available in the scientific literature.

Pork quality is of increasing importance to the meat industry, and comprehensive studies on genetically modified plants in pig nutrition, the fattening performance and the fate of foreign DNA in pig bodies as well as assessment of the quality of food produced from pigs fed GM crops are still needed to ensure the safety of genetically modified feeds.

\section{References}

A eschbacher K., Messikommer R., Meile L., Wenk C. (2005). Bt176 corn in poultry nutrition: physiological characteristics and fate of recombinant plant DNA in chickens. Poultry Sci., 84: 385-394.

A M S A (1991). Guidelines for meat color evaluation. Proc. 44th Annual Reciprocal Meat Conference, National Livestock and Meat Board, and American Meat Science Association, Manhattan, USA, pp. 232-249.

B e r e t a A., E c kert R. (2010). Histological profile of muscles is strictly related to pork quality (in Polish). Wiad. Zoot., XLVIII, 4: 65-70. 
Chainark P., Satoh S., Hino T., Kiron V., Hirono I., A oki T. (2006). Availability of genetically-modified soybean meal in rainbow trout Oncorhynchus mykiss diets. Fish Sci., 72: 1072-1078.

Cromwe 11 G.L., Lindem an M.D., Randolph J.H., Parker G.R., Coffey R.D., Lau rent K.M., A rm strong C.L., M i ke l W.B., S tan is i e w s k i E.P., H a r t ne 11 G.F. (2002). Soybean meal from Roundup Ready or conventional soybeans in diets for growing-finishing swine. J. Anim. Sci., 80: 708-715.

Fla chowsky G., A ulrich K., Böhme H., Halle I. (2007). Studies on feeds from genetically modified plants (GMP) - Contributions to nutritional and safety assessment. Anim. Feed Sci. Tech., 133: $2-30$.

Florowski T., Pis ula A., Słowiński M., Orzechowska B. (2006). Processing suitability of pork from different breeds reared in Poland. Acta Sci. Pol. Technol. Aliment., 5 (2): 55-64.

G a in e s A.M., A 11 e e G.L., R a 1 i ff B.W. (2001). Swine digestible energy evaluations of $B t$ (MON) and Roundup Ready corn compared with commercial varieties. J. Anim. Sci., 79 (Suppl. 1), p. 109.

Garni e r J.P., K lon t R., P l a s tow G. (2003). The potential impact of current animal research on the meat industry and consumer attitudes towards meat. Meat Sci., 63: 79-88.

Golding-Myers J.D., Showers C.D., Shand P.J., Ross er B.W.C. (2010). Muscle fiber type and the occurrence of pale, soft, exudative pork. J. Muscle Foods, 21: 484-498.

Hammond B.G., Vicini J.L., Hartnell G.F., Naylor M.W., Knight C.D., Robins o n E.H., Fuchs R.L., Padgette S.R. (1996). The feeding value of soybeans fed to rats, chickens, catfish and dairy cattle is not altered by genetic incorporation of glyphosate tolerance. J. Nutr., 126: 717-727.

Hyun Y., Bress ner G.E., E 11 is M., Lew is A.J., F is cher R., S t an is i ew ski E.P., Hart n e 11 G.F. (2004). Performance of growing-finishing pigs fed diets containing Roundup Ready corn (event NK603), a nontransgenic genetically similar corn, or conventional corn lines. J. Anim. Sci., 82: $571-580$.

Hyun Y., Bressner G.E., F is cher R., Miller P.S., E 11 is M., Peterson B.A., Sta$\mathrm{n}$ i s i e w s k i E.P., Hartne 11 G.F. (2005). Performance of growing-finishing pigs fed diets containing YieldGard Rootworm corn (MON863), a nontransgenic genetically similar corn, or conventional corn hybrids. J. Anim. Sci., 83: 1581-1590.

J a m e s C. (2009). Global status of commercialized biotech/GM crops: ISAAA Brief No. 41. ISAAA: Ithaca, NY.

Kanner J., Hazan B., Do 11 L. (1988). Catalytic free iron ions in muscle foods. J. Agric. Food Chem., 36: 412-415.

Magaña-Gómez J.A., Calderón de la B a r c a A.M. (2009). Risk assessment of genetically modified crops for nutrition and health. Nutr. Rev., 67: 1-16.

Mc Cann M.C., Li u K., Trujillo W.A., D obert C.D. (2005). Glyphosate-tolerant soybeans remain compositionally equivalent to conventional soybeans (Glycine max L.) during three years of field testing. J. Agric. Food Chem., 53: 5331-5335.

Min B., Ahn D.U. (2005). Mechanism of lipid peroxidation in meat and meat products - a review. Food Sci. Biotechnol., 14: 152-163.

M in B., N a m K.C., C or d r a y J., A h n D.U. (2008). Endogenous factors affecting oxidative stability of beef loin, pork loin, and chicken breast and thigh meats. J. Food Sci., 73: 439-446.

Mlynek J., Imrich I., Vavrišínová K., B obček B., Bučko O., Mlyneková E., Moravcová L. (2009). Use of fodder containing GM plants and their influence on production parameters in pigs. Res. Pig Breed., 3 (1): 23-31.

N a m K.C., Ahn D.U. (2003). Effects of ascorbic acid and antioxidants on the color of irradiated ground beef. J. Food Sci., 68: 1686-1690.

P a d get te S.R., T a y lor N.B., Nida D.L., B a il ey M.R., M a c D on ald J., Holden L.R., F u c h s R.L. (1996). The composition of glyphosate-tolerant soybean seeds is equivalent to that of conventional soybeans. J. Nutr., 126: 702-716.

Pikul J., Leszczyński D.E., Kummerow F.A. (1989). Evaluation of three modified TBA methods for measuring lipid oxidation in chicken meat. J. Agric. Food Chem., 37: 1309-1313.

Rossi F., Morlacchini M., Fusconi G., Pietri A., Mazza R., Piva G. (2005). Effect of $B t$ corn on broiler growth performance and fate of feed-derived DNA in the digestive tract. Poultry Sci., 84: 1022-1030. 
S o f o s J.N. (2008). Challenges to meat safety in the 21st century. Meat Sci., 78: 3-13.

Świ ątkiewicz M., Hanczakowska E., Twardowska M., Mazur M., Kwiatek K., Kozaczyński W., Świątkiew ic z S., Sieradzki Z. (2011). Effect of genetically modified feeds on fattening results and transfer of transgenic DNA to swine tissues. Bull. Vet. Inst. Pulawy, 55: 121-125.

W e b e r T.E., R i c h e r t B.T. (2001). Grower-finisher growth performance and carcass characteristics including attempts to detect transgenic plant DNA and protein in muscle from pigs fed genetically modified "Bt" corn. J. Anim. Sci., 79 (Suppl. 2), p. 67.

Wierbicki E., Tiede M.G., B urre11, R.C. (1962). Die Bestimmung der Fleischquellung als Methode zur Untersuchung der Wasserbindungskapazität von Muskelproteinen mit geringem Salthaltevermögen. Fleischwirtschaft, 10: 948-951.

Accepted for printing 17 VIII 2011

\section{JOANNA STADNIK, MAŁGORZATA KARWOWSKA, ZBIGNIEW JÓZEF DOLATOWSKI, MALGORZATA ŚWIĄTKIEWICZ, KRZYSZTOF KWIATEK}

\section{Wpływ pasz modyfikowanych genetycznie na właściwości fizykochemiczne wieprzowiny}

\section{STRESZCZENIE}

Celem pracy była ocena wpływu ziarna genetycznie modyfikowanej, odpornej na insekty kukurydzy Bt (MON810) oraz poekstrakcyjnej śruty otrzymanej z soi odpornej na glifosat (Roundup Ready MON40-3-2), jako składników diety świń, na fizykochemiczne właściwości mięsa.

W doświadczeniu wykorzystano 48 tuczników pochodzących od loch ( $\mathrm{pbz} \times$ wbp) pokrytych knurem $(\mathrm{Du} \times \mathrm{Pi})$. Wszystkie zwierzęta otrzymywały mieszanki paszowe o zbliżonej zawartości składników pokarmowych i energii metabolicznej, różniące się obecnością lub brakiem komponentów genetycznie modyfikowanych, według następującego schematu: grupa I (kontrolna) - śruta sojowa niemodyfikowana i kukurydza niemodyfikowana, grupa II - śruta sojowa GM i kukurydza niemodyfikowana, grupa III - niemodyfikowana śruta sojowa i kukurydza GM, grupa IV - śruta sojowa GM i kukurydza GM.

Ocena wartości pH schabu i mięśni karkówki nie wykazała istotnych różnic pomiędzy próbami pochodzącymi od zwierząt żywionych paszą zawierającą lub nie surowce genetycznie modyfikowane. Odnotowano brak statystycznie istotnych różnic wodochłonności (WHC) prób w obrębie badanych grup żywieniowych. Włączenie modyfikowanej genetycznie kukurydzy i soi do diety świń nie wpłynęło istotnie na wartość parametru a* barwy, zarówno schabu, jak i mięśni karkówki. Użycie modyfikowanej genetycznie kukurydzy i soi nie spowodowało istotnych zmian wartości parametru L* schabu. W przypadku mięśni karkówki wartości tego parametru były bardziej zróżnicowane, czego przyczyną mogła być naturalna niejednorodność tego elementu. Świnie żywione paszą z udziałem komponentów modyfikowanych genetycznie charakteryzowały się nieco niższą stabilnością lipidów zawartych w schabie, lecz różnice te zostały statystycznie potwierdzone jedynie w przypadku grupy II. Udział w paszy surowców modyfikowanych genetycznie nie wpłynął na stabilność tłuszczu mięśni karkówki, aczkolwiek wartości TBARS dla tych mięśni były dwukrotnie wyższe w stosunku do mięśni schabu. 